Birlesik Dünya Arastırma

BD-CENTER

Innovasyon ve Yayınıılık Merkezi

\section{Global Journal of Foreign \\ Language Teaching}

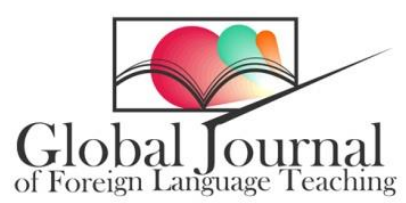

Volume 10, Issue 3, (2020) 191-197

www.gjflt.eu

\title{
Ethnography of communication: An analysis of Turkish education minister's speechon innovations
}

Ferhat Karanfil*, Bahcesehir University, Ciragan Cd., 34349 Istanbul, Turkey

Suggested Citation:

Karanfil, F. (2020). Ethnography of communication: An analysis of Turkish education minister's speech on innovations. Global Journal of Foreign Language Teaching. 10(3), 191-197.

https://doi.org/10.18844/gjflt.v10i3.5073

Received April 11, 2020; revised June 28, 2020; accepted August 24, 2020.

Selection and peer review under responsibility of Assoc Prof Dr. Ali Rahimi, Bangkok University, Thailand.

${ }^{\circledR} 2020$ Birlesik Dunya Yenilik Arastirma ve Yayincilik Merkezi. All rights reserved.

\begin{abstract}
Ethnography of communication (EOC)is an approach to discourse research that investigates the sequential organisation of talk as a way of accessing participants' understandings of and collaborative means of organising the forms of social interaction. The objective of the current research is to explore the speech of the education minister and how he uses his language indirectly talking on solid innovations. The sample online recordings of the education minister are transcribed in close detail to allow for a fine analysis of the design, exchange and coordination of actions within the delivery of new implementations. This article will introduce intellectual foundations of discourse analysis, outline its approach to data collection and transcription, illustrate its analytical procedures and discuss the application of EOC in the education minister's speech while addressing the teachers. The results suggest that the use of indirectness and implicit speech-making strategies fosters the politeness act in public speech. We can conclude that the politician's speech delivered to the public may be researched more and it might be a part of discourse competence for English language learners. The future direction of EOC may focus on a transnational context by comparing the different countries and education minister's speech which may help English teachers to teach culture and spoken discourse better.
\end{abstract}

Keywords: Ethnography of communication, educational leadership, discourse, speech community, speech event.

* ADDRESS FOR CORRESPONDENCE: Ferhat Karanfil, Bahcesehir University, Ciragan Cd., 34349 Istanbul, Turkey.

E-mail address: Ferhat.Karanfil@bahcesehir.edu.tr 


\section{Introduction}

Sprain and Boromisza-Habashi (2013, p. 183) describe the ethnography of communication (EOC) as a practical endeavour as it focuses on the two tasks of 'building cultural competence and designing strategic action'. In particular, ethnographers are committed to understanding what counts as competent communication for a community of speakers by exploring what Hymes (1962) calls the means and meanings of communication for its users. This cultural knowledge can then be used to assess and assist practitioners' strategic actions (Boromisza-Habashi, 2013). One predominant premise of communication ethnography is that human communication comprises of excellently identified units, i.e., speech events that are constrained by social and cultural norms. To put it in Hymes' (1962, p.132) words, 'the community is organised as systems of speech events'. Bakhtin (1986, pp.126-128) further claims that 'speech genres (events) organise our speech in almost the same way as grammatical forms do', suggesting that understanding communication necessitates an investigation of speech events. The EOC approach provides a framework to 'study local strategies for strategic action' and potentially improve the strategies by applying local knowledge of culturally competent communication (Sprain \& Boromisza-Habashi, 2013, p. 184).Opening speeches while introducing a new idea or innovation carry great importance. Turn construction component in the speeches of the Turkish education minister's speech (EPM) is often favoured by teachers and university lecturers. People generally associate this success from a skilled speaker, creating ground with all stakeholders regarding education. To further investigate the strategies, he employs, while delivering his speech, the voice recordings while introducing a new journal called 'Ya da' (https://yadadergi.com/iletisim/), which is an intended meaning in education. The way that he delivers his speech is remarkable as he speaks indirectly about the journal.

EOC defines language as a system of use of which rules and standards are an indispensable part of the culture and that culture is periodically generated, negotiated and redefined in the concrete actions of parties involved in some manner of interactive situation. Thus, the way we communicate is not only constrained by culture, but it also reveals and gives strength to the culture (Malinowski, 1978; Saville-Troik, 1989). In other words, by studying the language we use in speech situations, we can realise the cultural norms that underlie the way we act towards one another. That is why, Hymes (1974), who has adapted this view into an approach to discourse analysis, categorised communication into hierarchical units, namely: (a) speech scenario: the behavioural context in which the verbal interaction takes place and characterises the verbal traits (e.g., a birthday party, an encounter); (b) speech incident: speech that occurs in a speech situation with identifiable parameters (e.g., a baby shower dialogue, a meeting joke);and (c) speech act: individual expression characters that help people to identify the speech and its unique forms. Hymes (1962, p.132) also identified the speech event as the 'primary object of analysis' and proposed an ethnographic framework which considers the numerous factors involved in speaking, with the help of a classificatory scale known as the Speaking Grid. The ethnography of written communication is a concern for the researchers. The scholars conducted studies on written communication in different countries (Fatma, Prayitno, Jamaludin, Jha \& Badri, 2019; Sorce, 2019)

The research hypothesis is that the findings of the current study and the models of speech delivery will help other education leaders to deliver efficient talks in an ethnographic awareness way and to unlock the systems he uses while delivering their speech.

The management of educational change is one of the pillars of the study and the PME is achieving success in making the education better. However, a scientific inquiry was done in Philippines to manage the change process in a scientific manner. The detailed process of change management in education case study (Vilches, 2018) is one of the motivations to take up the current research. 


\section{Data collection and analysis methods}

The education context in Turkey has experienced many swift changes before; the current education minister is outstanding with his mindful decision-making process. As the sample of the study, the current education minister is deemed to be a topic of the study as he is a professor of educational sciences in Turkey and shares education meta-language with teachers. The researcher worked closely with the minister of education on his visits to İstanbul, and on five different occasions the researcher recorded his voice. The researcher recorded the education EPM's voice online on a mobile phone application. It is presumed that the evaluation of dozens of cases would contribute to the quality of formulation, as ethnographic descriptions are based mainly on the knowledge and heritage of the investigator along with the experiences as a 'recipient-observer' in the event (Schiffrin, Tannen \& Hamilton, 2001). The recordings were coded by hand and analysed with another rater holding amaster's degree in English language teaching to provide trustworthiness as ethnomethodology of communication requires, to some extent, subjectivity.

\section{Speaking Grid and its components}

\subsection{The Speaking Grid}

The Speaking Grid, which was used as an analytical tool in this review, helped to identify potential verbal and non-verbal aspects of discrete speech events and also to clarify how these characteristics are interrelated. Each letter represents one component of communication that needs to be analysed S-P-E-A-K-I-N-G (Wardough, 1997)

(S) Setting or Scene: Although the environment or setting describes the physical conditions, such as duration, the place of occurrence, the scene refers to psychological/abstract environments.

The scene of the president's economic growth message would broadly differ from the scene of a message following an earthquake that hits the country. The setting in the current study is the place known as Hababam Sinifi Museum and participants from different backgrounds were invited.

(P) People involved: It includes different speaker-listener and sender-receiver combinations.

The addressee-addresser, etc., as they typically occupy socially established positions, e.g., in a classroom environment, not only does the teacher's question accompanied by the student's answer include the two interactants, but it also assigns the role of 'attentive listeners' to the rest of the students. In the current study, the minister of education is addressing the teachers and journalists before launching a journal.

(E) Ends not only refer to the traditionally acknowledged and anticipated consequences or purposes of the event but also includes the interactants' specific targets. So, e.g., a criminal case in a courthouse has a distinctive functional purpose, but various participants (e.g., attorneys or defence lawyers) also have their own strategic goals. In the current study, the education minister ends the speech by asking for written contributions to the journal from the teachers in the room.

(A) Act-sequence alludes to the initial form of what is being said and its content. This part is the core aspect of speech activities that are fields of linguists. Act and sequence details are elaborated in the data analysis part.

(K) Key refers to the tone and form or soul in which a unique message is being conveyed. Key can be luminous-hearted, extreme, sarcastic and joyful. We can conclude the tone in the stretches of his conversation is persuasive and informative.

(I) Instrumentalities are attributed to the channel (verbal/non-verbal), physical forms of speech, verbal or written, and so forth. A single event may involve all uses of multiple instruments; e.g., verbal 
and non-verbal modes or language switches. The current study examines an oral presentation and its effect on the audience.

(N) Norms of interaction and interpretation describe the interaction and perception criteria that apply to specific properties added to the speech by the speech community concerning cultural traditions, behaviours and patterns. In the analysis data, we can observe how the educational discourse is being used for the audience. In a similar view, Mey and Xu (2001) suggested that conversation discourse data explore the traffic rules of conversation analysis.

(G) Genre applies to evidently categorised categories of text, for example, sonnets, remarks and seminars.

Act: Introduction EPM EPM1: Ulkemizin degerli sanat ve fikir temsilcileri, degerli meslektaslarim saygideger velilerimiz hepiniz hosgeldiniz (0.19)

EPM1: 'Dear valuable idea and fine arts representatives, $\downarrow$ dear colleagues and respectable parents, I want to welcome you all.' (0.19)

Participants: Applause

After waiting for approximately 20seconds for clapping to finish, he continues:

Act: Involving the participants in the journey, creating a common ground: 'Gozlerimgorseydi, to pragigoremezdim.' diyor Asik Veysel, bizeger gercekten goreceksek hep beraber gormek durumundayiz. (0.40)

EPM2: 'If my eyes were able to see, I could not see the soil says Asik Veysel (Turkish folk poet). If we actually see, we need to see it all together.'

Meyerhoff (2018) found out that we derived extraordinarily strong conclusions from the way they speak about people and abstractly continues the speech:

Minimising the expectations via abstract messages: Ve: bakmakla gormek arasindaki farkiyeniden insa etmek durumundayiz. (0.46)

Informing about main and sub-aims: 'Ya da'dergisinin isminden baslayarak bir mesaj verme kaygisivb. bir Beklentisi yok. Biz sadece diyalektik olarak baska perspektifler de var, baska bakisacilarida var demeye calisiyoruz (1.15)

EPM3: 'And we are supposed to build the difference between looking and seeing again. (0.46) The journal "Ya da" (Or) has no concern to give messages, no expectations. In dialectic terms, we just want to there are other ways of doing things and looking things.' (1.15)

He implies the divergent thinking in the 21st century and higher-order thinking skills and in a way he wants to build the respect to other ways of thinking. Hubers (2020) offers that the educational decision-makers aim for a sustainable education change with the involvement of stakeholders. The PME of education offered other ways of doing things as a problem-solving method in the extract.

Reminding the targets again: Bulundugumuz bakisacilaridisinda bakisacilarina davet ediyoruz. (1.33)

EPM4: 'We invite you the employ other perspectives on things rather than using what we have now.'

The first 2 minutes were spent on giving the insight on how this new journal should be perceived and he continues informing the audience about the big ideas in the journal:

Bir meseleye 'sudur' ya da 'budur' demek yerine hem 'o' hem de 'o' demek istiyoruz. Yani hem 'hem de' derken hem 'YA DA' derken aslinda vermek istedigimiz mesaj oncelikle kendimize. Diyoruz ki, eger tabiata da bakarsak bir miknatista eksi ya da artikutuptan soz ettigimizde, artiya da eksi kutup 
kendi basina bir islev gormuyor, iki kutup temas ettiginde elektrik ortaya cikiyor. Bu temasa daha cok ihtiyacimiz var. Bir mutabakata daha cok ihtiyacimiz var. (2.31)

He used examples from nature to support his viewpoints and make his discussion more resilient. The education minister used the 'magnifier' as an example from nature. Deschouwer and Temmerman(2012) analysed metaphors used by four leading politicians in Belgium and found that metaphorsarean idiosyncratic language tool and some speakers use it a lot more systematically than others. Metaphors tell us about the intended meaning with a strong impact on the audience.

EPM5: Supporting Act (Restating the need for the act of negotiation, wholeness) 'Instead of saying this or that about an issue, we want to say both this and that. In other words, in saying as well or "YA DA" our message is actually intended for ourselves. What we say is if you look at nature, positive pole or negative pole do not function by themselves but when they touch together, they produce electricity. We need this contact more and more-. We need $\sim$ mutual understanding more.'

Remarkably, the minister always used 'we', a pronoun, and inclusive language. Discourse research in political communication has recently paid a lot of attention to the deixis of pronouns (Bull \& Fetzer, 2006). Especially, the pronoun of the first-person plural ('we') receives a lot of attention in these times of division in which the need is felt to define groups and memberships. Kvam (2017) associates the communication competence with the EOC while supporting Mexican immigrant settlement in United States of America and it proved to be effective.

The EPM continues his speech by saying:

Cep telefonlarimizin ve sahsi dunyamizin birikimiyle degil, Turkiye'nin ve dunyanin birikimiyle bir arada olmak zorundayiz. Bu yuzden de Turkiye'nin birikimini cok onemsiyoruz. Bugunkukultur dunyamizdaki insanlarimizin, buyuk beyinlerimizin gosterdigi cabalaributun toplumla paylasmak istiyoruz. Onlarin kelime dagarciklarinicocuklarimizla karsilastirmak istiyoruz. (3.13)

EPM6: 'Not with the accumulation of mobile phones or ourselves. We have to be together with the savings of Turkey and the world, so we attach great importance to the intellectual reservoir of Turkey. We want to share the endeavours of today's people and the big brains of our society. We want to share the knowledge with you all and compare their mental lexicon with our children' (3.13)

In the sixth extract, it is confusing as to why he mentioned we could not build the culture with mobile phones. It might be their common usage, or it may not come as a surprise that politicians themselves have embraced a more personalised discourse of convenience and standards of lifestyle to communicate their political messages to people (Simpson \& Andrea, 2010)

Bu dergide gecen kelimelerin sinifin icerisinde ogretmen tarafindan tekrar edilmesini onemsiyoruz. Yazarlarimizin, birikimi olan muhtesem insanlarimizin zihin dunyasinin siniflarin icerisine organik olarak girmesini cok degerli buluyoruz.' (3.50). Bentum meslektaslarimizdan hususi destek bekliyorum, dergininyasamasiicin icerik katkisibekliyorum.Baktigimizda butun ulkelerde bu turden dergiler var hepimizin bildigi time dergisi 1923' ten beri, Economist dergisi 1843' den beri, National Geoprahic $1888^{\prime}$ den beri yayina devam ediyor. Budevamlilik bu dergilerin sadece idari veya ticari bir basarisidegildir. Budevamlilik bir medeniyetin kendi cizgisini korumasimeselesidir. Tesekkurler.... (4.22)

Head Act: Comparing with other nationalities 'We give importance to revising the words that took place in this journal by our teachers. We find unbelievably valuable our magnificent people's intellectual heritage organically enters the classroom. (3.50). I want special support from all my colleagues, to sustain the journal. In other countries we examined, there are journals we all know, Times has been publishing since 1923, Economist has been publishing since 1843, National Geographic has been publishing since 1888. This continuity is not an administrative or commercial success; it is rather the civilisation keeping its line. Thank you' (4.22)

The key decision-makers could also make us the EOC in their speech (Sorce, 2019). While introducing a change, it is vital to constitute team spirit in both the business world and education. 
Carbaugh (2016) proposes that we live in a cross-cultural and multilingual countries and implementing change-taking vulnerabilities of different folks living in a country is of essence. In Turkey, for instance, there are nationals from multiple countries and the implementations will affect everybody's life in some ways, as the extract above proposes.

\section{Conclusion}

As the last extract suggested, the EPM has only compared to his country with others to provide examples of good practice and evidence. He does not include talk about the details of the journal (page numbers, layout, editors and so on). The audience that took part in the event and who were interviewed after the speech felt incredibly pleased with his speech. Why the teachers do like his changes? There might be many explanations for this, but one strong claim is explained by Wiseman. Wiseman (2010) argues that the rise of new public management has been accompanied in education by new forms of accountability. In this context, he suggests that evidence-based educational policymaking has become a global phenomenon. Novoa and Yariv-Mashal (2003) argued that analogy has become central to contemporary forms of governance and that comparison today is global and operates within nations and works by numbers at both levels, although he used comparisons in the last part to give concrete examples. We can conclude that in that speech event some indirect strategies were employed, like talking about the journal in a less explicit way, as well as Saville-Troike (1989) studies of devotional and official events will become a field for examining speech events which are part of daily communication and which are more loosely organised and thus less structured, providing pleasantries for the audience to make them satisfied with the speech content. The unpredictable nature of political speech events makes the audience more focused and curious about the content. In EOC, special attention should be paid to whether a predictable everyday conversation or focused formal talks are being analysed; therefore, the results may give implications for others to reflect upon. Barley, Bechky and Nelsen (2016) used the EOC in technicians while addressing change; however, as a research practitioner, I will suggest that the EOC should be used in educational practices as well. Teachers act as a mediator in the implementation of change in education and also serve as a bridge among parents and students. Using the principles of the EOC is going to bring the feeling of togetherness in education.

\section{References}

Bakhtin, M. M. (1986).The problem of speech genres. In A. Coupl and and N. Jaworsky (Eds.), Discourse reader (pp.121-133).London, UK: Routledge.

Barley, S. R., Bechky, B. A. \& Nelsen, B. J. (2016). What do technicians mean when they talk about professionalism? An ethnography of speaking. In L. E. Cohen, M. D. Burton, and M. Lounsbury (Eds.), The structuring of work in organizations. Bingley, UK: Emerald Group Publishing.

Boromisza-Habashi, D. (2013). Speaking hatefully: culture, communication, and political action in Hungary. University Park, TX: The Pennsylvania State University Press.

Bull, P. \& Fetzer, A. (2006). Who are we and who are you? The strategic use of forms of address in political interviews. Text andTalk,26(1), 3-37.

Carbaugh, D. (Ed.). (2016). The handbook of communication in cross-cultural perspective. Abingdon, UK: Taylor \& Francis.

Deschouwer, K. \& Temmerman, M. (2012). Elite behaviour and elite communication in a divided society: the Belgian federal coalition formation of 2007.Journal of Language and Politics, 11(4), 500-520.

Fatma, F., Prayitno, H. J., Jamaludin, N., Jha, G. K. \& Badri, T. I. (2019). Directive speech acts in academic discourse: ethnography of communication from gender perspective in higher education. Indonesian Journal on Learning and Advanced Education (IJOLAE), 2(1), 27-46.

Hubers, M. D. (2020). Paving the way for sustainable educational change: reconceptualizing what it means to make educational changes that last. Teaching and Teacher Education, 93, 103083. 
Hymes, D. (1962). The ethnography of speaking. In T. Glandunt and W. Stewart (Eds.), Anthropology and human behavior (pp.13-53). Washington, DC: The Anthropology Society of Washington.

Hymes, D. (1974). Foundations in sociolinguistics: an ethnographic approach. Philadelphia, PA: University of Pennsylvania Press.

Kvam, D. S. (2017). Supporting Mexican immigrants' resettlement in the United States: an ethnography of communication approach to building allies' communication competence. Journal of Applied Communication Research, 45(1), 1-20.

Meyerhoff, M. (2018). Introduction to sociolinguistics. Abingdon, UK: Routledge.

Mey, J. L. \& Xu, C. (2001). Pragmatics: an introduction (2nd ed.). Hoboken, NJ: Blackwell, Publishing.

Novoa, A. and T. Yariv-Mashal. (2003). Comparative research in education: a mode of governance or a historical journey? Comparative Education, 39(4): 423-438.

Saville-Troike, M. (1989). The analysis of communicative events. In A. Coupland and N. Jaworsky (Eds.), Sociolinguistics: areader (pp.126-145). New York, NY: St. Martin's Press.

Schiffrin, D., Tannen, D. \& Hamilton, H. E. (Eds.). (2001).The handbook of discourse analysis (p. 54). Oxford, UK: Blackwell.

Seggie, F. N. \& Bayyurt, Y. (Eds.). (2017). Nitel arastirma: Yontem, teknik, analiz veyaklasimlari (pp. 267-278). Ankara, Turkey: AniYayincilik.

Sert, O. \& Seedhouse, P. (2011). Introduction: conversation analysis in applied linguistics. Novitas-Royal, 5(1).

Simpson, P. \& Andrea, M. (2010). Language and power. Abingdon, UK: Routledge.

Sorce, G. (2019). Institutional ethnography for communication and media research. The Communication Review, 22(4), 296-308.

Sprain, L. \& Boromisza-Habashi, D. (2013). The ethnographer of communication at the table: building cultural competence, designing strategic action. Journal of Applied Communication Research, 41(2), 181-187. doi:10.1080/00909882.2013.782418

Vilches, M. L. C. (2018). Involving teachers in the change process: one English language teacher's account of implementing curricular change in Philippine basic education. In International perspectives on teachers living with curriculum change (pp. 15-37). London, UK: Palgrave Macmillan.

Wardough, R. (1997). An introduction to sociolinguistics. Hoboken, NJ: Blackwell Publishers.

Wiseman, A. (2010). The uses of evidence for educational policymaking: global contexts and international trends. What counts as evidence and equity? In A. Luke, J. Green, and G. Kelly (Ed.), Review of research in education (pp. 1-24). AERA, Sage. 